\title{
Communication
}

\section{Increasing Trends Towards Drinking Water Reclamation from Treated Wastewater}

\author{
Djamel Ghernaout ${ }^{1,2,3}$ \\ ${ }^{1}$ Chemical Engineering Department, College of Engineering, University of Ha'il, Ha'il, Saudi Arabia \\ ${ }^{2}$ Binladin Research Chair on Quality and Productivity Improvement in the Construction Industry, College of Engineering, University of Ha'il, \\ Ha'il, Saudi Arabia \\ ${ }^{3}$ Chemical Engineering Department, Faculty of Engineering, University of Blida, Blida, Algeria
}

Email address:

djamel_andalus@hotmail.com

\section{To cite this article:}

Djamel Ghernaout. Increasing Trends Towards Drinking Water Reclamation from Treated Wastewater. World Journal of Applied Chemistry. Vol. 3, No. 1, 2018, pp. 1-9. doi: 10.11648/j.wjac.20180301.11

Received: November 10, 2017; Accepted: November 17, 2017; Published: December 5, 2017

\begin{abstract}
All around the world, water supplies are coming under increasing pressure as population growth, climate change, pollution, and changes in land use affect water quantity and quality. To address existing and anticipated water shortages, many communities are working to increase water conservation and are seeking alternative sources of water. Water reuse - the use of treated wastewater, or "reclaimed" water, for beneficial purposes such as drinking, irrigation, or industrial uses — is one option that has helped some communities significantly expand their water supplies. This review summarizes the main findings of the literature. The paper provides an overview of the options and outlook for water reuse in the world, discusses water treatment technologies and potential uses of reclaimed water, and presents a new analysis that compares the risks of drinking reclaimed water to those of drinking water from traditional sources. Involved technologies in wastewater treatment plant for drinking water purpose should be furnished with highly performant methods such as membrane processes (nanofiltration, reverse osmosis) and advanced oxidation processes $\left(\mathrm{H}_{2} \mathrm{O}_{2}, \mathrm{O}_{3}\right.$, etc.). Treating efficiently wastewater at its source is the best "barrage" against pollutants diffusion through the nature as chemicals of emerging concern are detected in tap water.
\end{abstract}

Keywords: Water Scarcity, Water Reuse (WR), Drinking Water, Human Health, Water/Wastewater Treatment, Environmental Principles

\section{Introduction}

For developing country planners and decision makers, water will be the key resource and political consideration in the coming 50 years. In many of these nations and regions, how water is managed will make the difference between peace and conflict; poverty and prosperity [1-9]. Across the globe, 2 out of 10 people do not have access to safe drinking water, and in the US, many states face water shortages and droughts [10]. As an example, it was reported that Americans use 90 litters of water each day to flush their toilets [11]. As the global population continues to grow and climate change results in more water crises, finding enough water will be harder.

In the US, billions of dollars are spent in treating water to drinking water quality when only $10 \%$ of it is used for drinking and cooking, and then flush most of the rest down the toilet or drain. So the growing use of recycled wastewater for irrigation, landscaping, industry and toilet flushing, is a good way to conserve our fresh water resources. Recycled water is also used to replenish sensitive ecosystems where wildlife, fish and plants are left vulnerable when water is diverted for urban or rural needs. In coastal areas, recycled water helps recharge groundwater aquifers to prevent the intrusion of saltwater, which occurs when groundwater has been over pumped.

The use of recycled water for drinking, however, is less common, largely because many people are repelled by the thought of water that's been in our toilets going to our taps. But some countries like Singapore, Australia and Namibia, and states such as California, Virginia and New Mexico are 
already drinking recycled water, demonstrating that purified wastewater can be safe and clean, and help ease water shortages. The term "toilet to tap," used to drum up opposition to drinking recycled water, is misleading because recycled water that ends up in drinking water undergoes extensive and thorough purification. In addition, it is usually added to groundwater or surface water for further cleansing before being sent to a drinking water supply where it is again treated. In fact, it has been shown to have fewer contaminants than existing treated water supplies.

There are a number of technologies used to recycle water, depending on how pure it needs to be and what it will be used for [12-15]. At the Point Loma Wastewater Treatment plant in San Diego, the city is currently studying the feasibility of recycling water for drinking. Sewage [16, 17] first goes through advanced primary treatment in which water is separated from large particles, then enters sedimentation tanks where chemicals are used to make primary sludge settle to the bottom and scum rise to the top. Once the water is separated out, $80 \%$ of the solids have been removed, and the wastewater is clean enough to be discharged to the nature [18-21]. In secondary treatment, bacteria are added to the wastewater to ingest organic matters, producing secondary sludge that settles to the bottom $[18,20,22]$. Tertiary treatment filters the water to remove whatever solids remain, disinfects it with chlorine, and removes the salt $[23,24]$. In California, tertiary-treated water is called "recycled water" and can be used for irrigation or industry.

For indirect potable reuse, recycled water that eventually becomes drinking water, tertiary-treated water undergoes advanced water technology, and then spends time in groundwater or surface water, such as a reservoir, before being sent to drinking water supplies. Advanced water technology first involves microfiltration that strains out any remaining solids [25]. Next, reverse osmosis, which applies pressure to water on one side of a membrane allowing pure water to pass through, eliminates viruses, bacteria, protozoa, and pharmaceuticals. The water is then disinfected by ultra violet light (UV) or ozone and hydrogen peroxide. Finally, it is added to groundwater or surface water reservoirs where it stays for an average of 6 months to be further purified by natural processes. This is done mainly to assuage public anxiety about drinking recycled water. Once drawn from the groundwater or reservoir, the recycled water goes through the standard water purification process all drinking water undergoes to meet US Environmental Protection Agency standards $[22,26]$.

Singapore, with no natural aquifers and a small landmass, has struggled to provide a sustainable water supply for its residents for decades. In 2003, it opened the first plants to produce NEWater, recycled drinking water purified by advanced membrane techniques including microfiltration, reverse osmosis and UV disinfection. After treatment, the water is added to the reservoirs. NEWater, which has passed more than 65,000 scientific tests and surpasses World Health Organization drinking water standards, is clean enough to be used for the electronics industry and to be bottled as drinking water.

Namibia, the most arid country in southern Africa, has been drinking recycled water since 1969 . The water reclamation plants produce $35 \%$ of the water for Windhoek, the capital city. To date, there have been no negative health impacts connected with the consumption of recycled water [22].

Researchers examined the potential human health implications of "chemicals of emerging concern" (CECs) such as pharmaceuticals, pesticides, and industrial chemicals, in recycled water [27]. Anderson et al. [27] reviewed epidemiological and other studies of recycled water from the last 40 years. While some early studies reported the presence of chlorine disinfection by-products (DBPs), they noted that treatment methods at that time were less sophisticated. Current methods have been refined and DBPs have decreased. More recent studies of recycled water found no adverse health effects in populations using recycled water. Though the scientists acknowledged that the effects of long-term exposure (over generations) to CECs and to substances that have not yet been detected are unknown, they concluded that there was "robust evidence that recycled water represents a source of safe drinking water."

This review summarizes the main findings of the literature concerning water reuse. The paper provides an overview of the options and outlook for water reuse in the world, discusses water treatment technologies and potential uses of reclaimed water, and presents an analysis that compares the risks of drinking reclaimed water to those of drinking water from traditional sources.

\section{Water Reuse}

Water reuse offers an opportunity to significantly expand supplies of freshwater in communities facing water shortages. Coastal areas of the United States, for example, discharge 45 billion litters of wastewater into estuaries and oceans every day - an amount equivalent to six percent of the country's total daily water use. Reusing this water would directly augment the nation's total water supply [7-9, 11, 28-30].

In conventional municipal water systems, water from a river, lake, or aquifer is treated to meet drinking water standards before being distributed for all uses. After the water is used, the community's wastewater - the water that flows down the drain or is flushed down the toilet-is treated to remove pollutants before it is discharged into downstream water bodies [11].

Water reuse is the use of treated wastewater for beneficial purposes (Figure 1), which increases a community's available water supply and makes it more reliable, especially in times of drought $[7-9,11,28,29,31-35]$. 


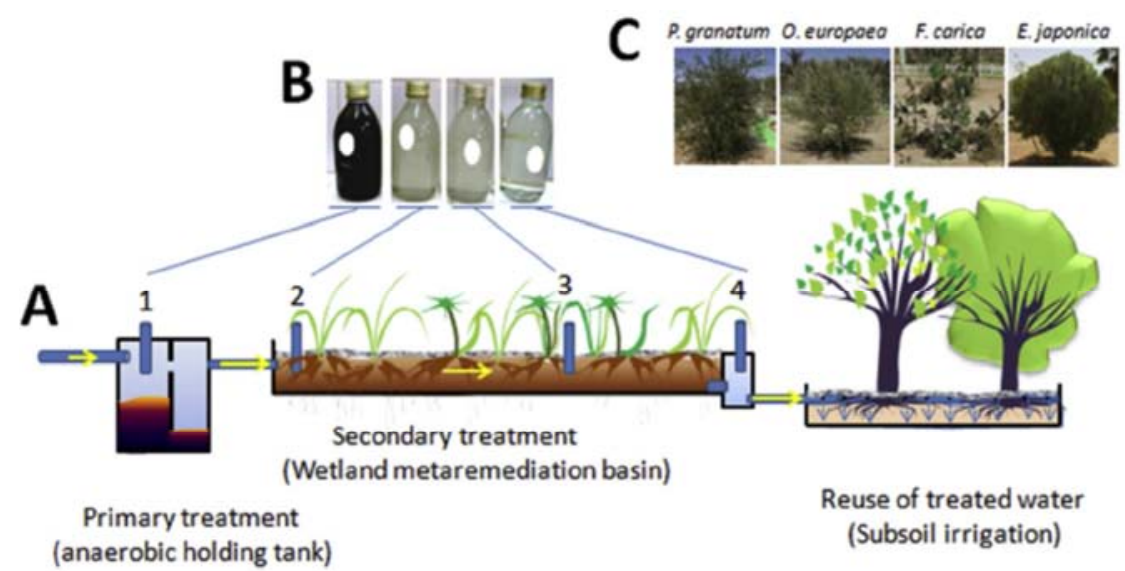

Figure 1. Schematic representation of the pilot station. A. The primary treatment occurred in an anaerobic septic tank. The yellow arrows show the gravity flow. The resulting treated water was reused by gravitational flow to irrigate a field with crops and trees. B. Visual observation of wastewater samples collected at different point as depicted by the pipes 1,2, 3 and 4. C. Phenotypical and morphological aspects of agronomical and commercial species developed in the subsurface irrigation field during the eight-year trial [9].

Figure 2 presents a summary of some other advanced reuse milestones is presented [36].

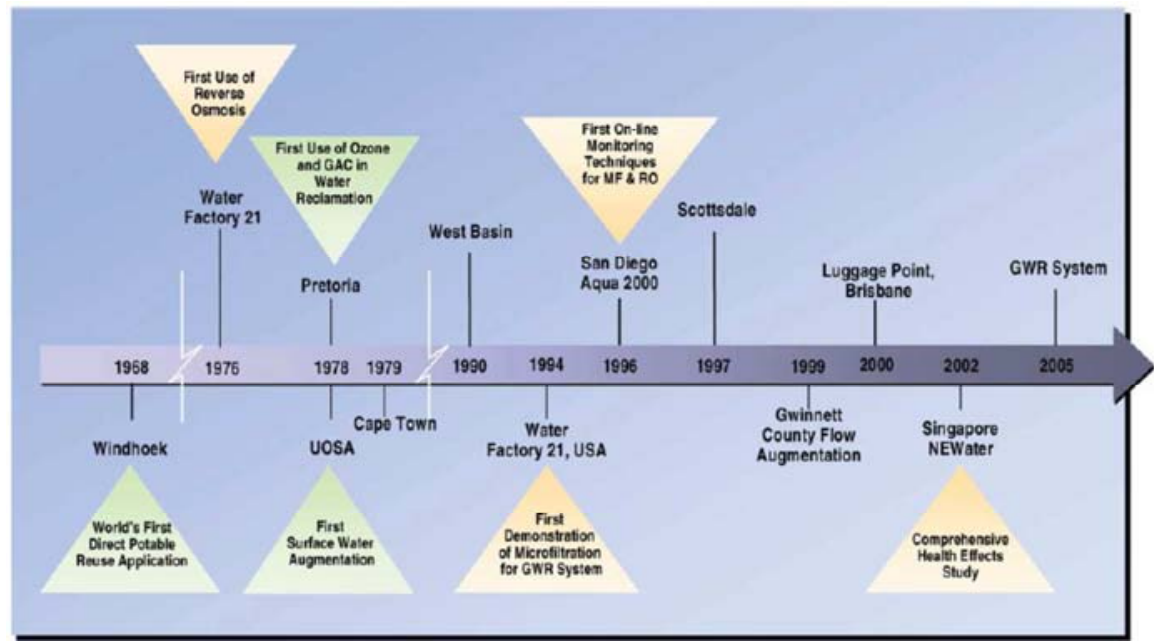

Figure 2. Salient milestones in advanced reuse applications [36].

\section{Water Reuse Types and Applications}

Most of the uses of water reclamation are non-potable uses such as: washing cars, flushing toilets, cooling water for power plants, concrete mixing, artificial lakes, irrigation for golf courses and public parks, and for hydraulic fracturing.
Where applicable, systems run a dual piping system to keep the recycled water separate from the potable water [37-39]. The main reclaimed water applications in the world are shown in Table 1 [6-9, 33, 37, 40-47].

Table 1. Main reclaimed water applications in the world [6, 9, 37, 40, 41$]$.

\begin{tabular}{ll}
\hline Categories of use & Uses \\
\hline Urban uses & $\begin{array}{l}\text { Irrigation of public parks, sporting facilities, private gardens, roadsides; Street cleaning; Fire protection systems; } \\
\text { Vehicle washing; Toilet flushing; Air conditioners; Dust control. }\end{array}$ \\
& $\begin{array}{l}\text { Food crops not commercially processed; Food crops commercially processed; Pasture for milking animals; } \\
\text { Fgricultural }\end{array}$ \\
$\begin{array}{l}\text { Fodder; uses Fibre; Seed crops; Ornamental flowers; Orchards; Hydroponic culture; Aquaculture; Greenhouses; Viticulture. } \\
\text { Processing water; Cooling water; Recirculating cooling towers; Washdown water; Washing aggregate; Making concrete; Soil } \\
\text { compaction; Dust control. }\end{array}$ \\
$\begin{array}{l}\text { uses } \\
\text { Recreational } \\
\begin{array}{l}\text { uses } \\
\text { Environmental }\end{array}\end{array}$ \\
$\begin{array}{l}\text { Golf course irrigation; Recreational impoundments with/without public access (e.g. fishing, boating, bathing); } \\
\text { Potable uses }\end{array}$ & $\begin{array}{l}\text { Aquifer recharge; Wetlands; Marshes; Stream augmentation; Wildlife habitat; Silviculture. } \\
\text { Aquifer recharge for drinking water use; Augmentation of surface drinking water supplies; Treatment until drinking water quality. }\end{array}$ \\
\hline
\end{tabular}




\section{Assessing the Risks of Potable Water Reuse}

Researchers [11] conducted an analysis that compares the estimated risks of drinking water from two potable reuse projects to a de facto reuse scenario in which five percent of the source water comes from wastewater discharged upstream after secondary treatment $[5,7-9,28,37]$. The assumed de facto reuse conditions of Scenario 1 are likely typical in many places and are generally perceived as safe. In Scenario 2, treated wastewater is allowed to filter slowly through surface soils into an aquifer (also called soil aquifer treatment) before potable reuse [37]. In Scenario 3, advanced treatment techniques including microfiltration, reverse osmosis, and advanced oxidation are employed before the water is injected into an aquifer and used as a source of drinking water [11]. Figure 3 illustrates all three Scenarios.

The analysis compared the risks of exposure to four pathogens (adenovirus, norovirus, Salmonella, and Cryptosporidium) and 24 chemical contaminants including pharmaceuticals, personal care products, natural hormones, industrial chemicals, and by-products from water disinfection processes. The graph in Figure 4 shows only the four pathogens [11].

a)

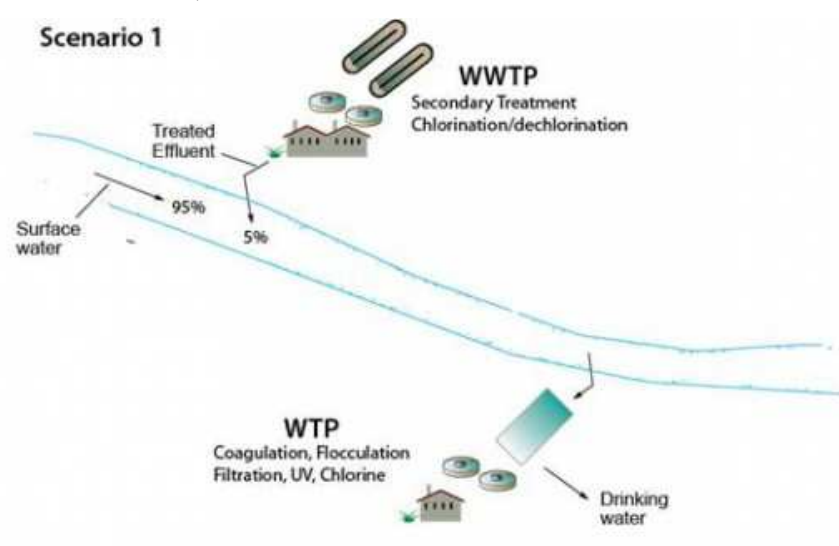

b)
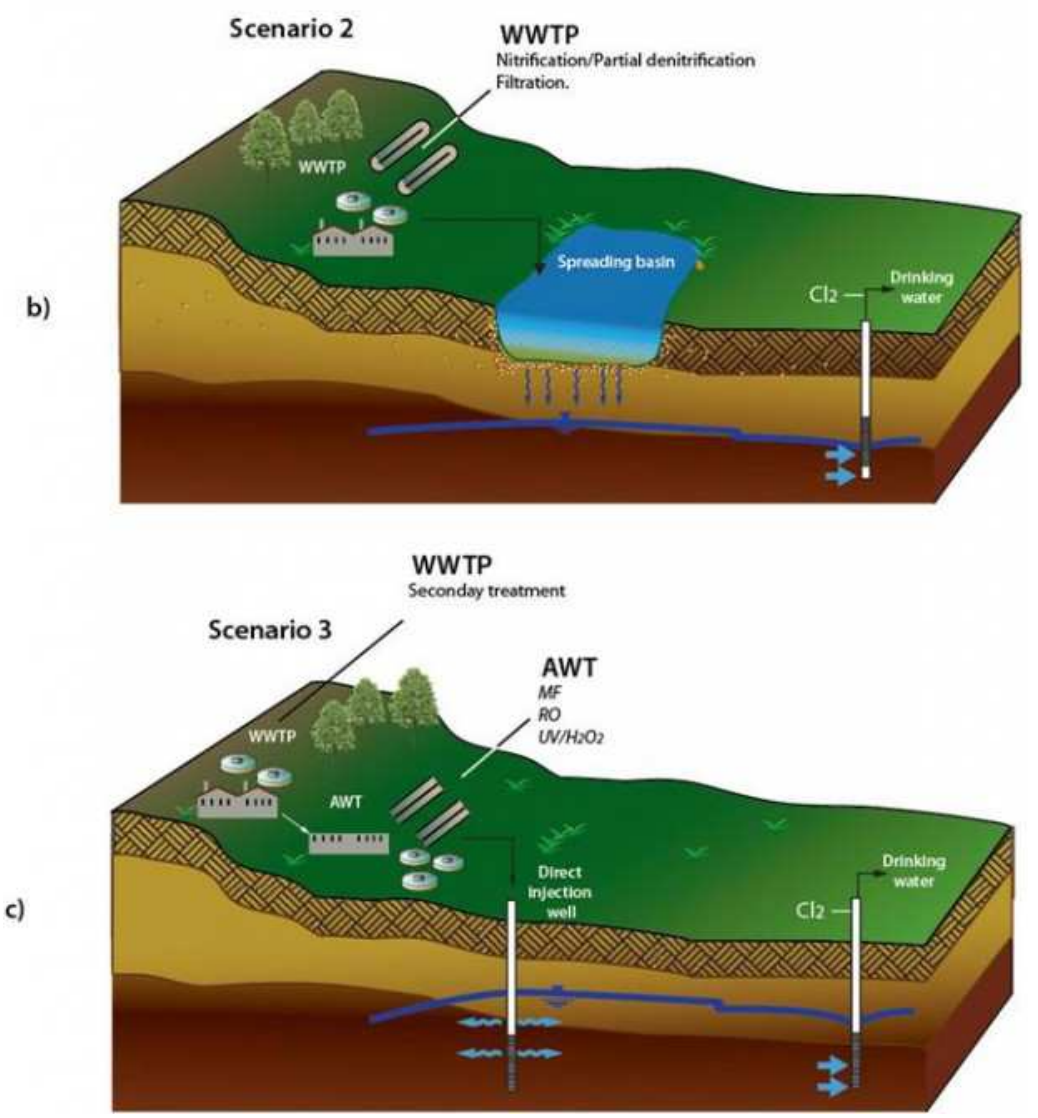

Figure 3. Summary of Scenarios examined in the risk exemplar. Scenario 1: a conventional water plant drawing from a source that is 5 percent treated wastewater in origin. Scenario 2: a deep well in an aquifer fed by reclaimed water via a soil aquifer treatment system. Scenario 3: a deep well drawing from an aquifer fed by injection of reclaimed water from an advanced water treatment plant [11]. 


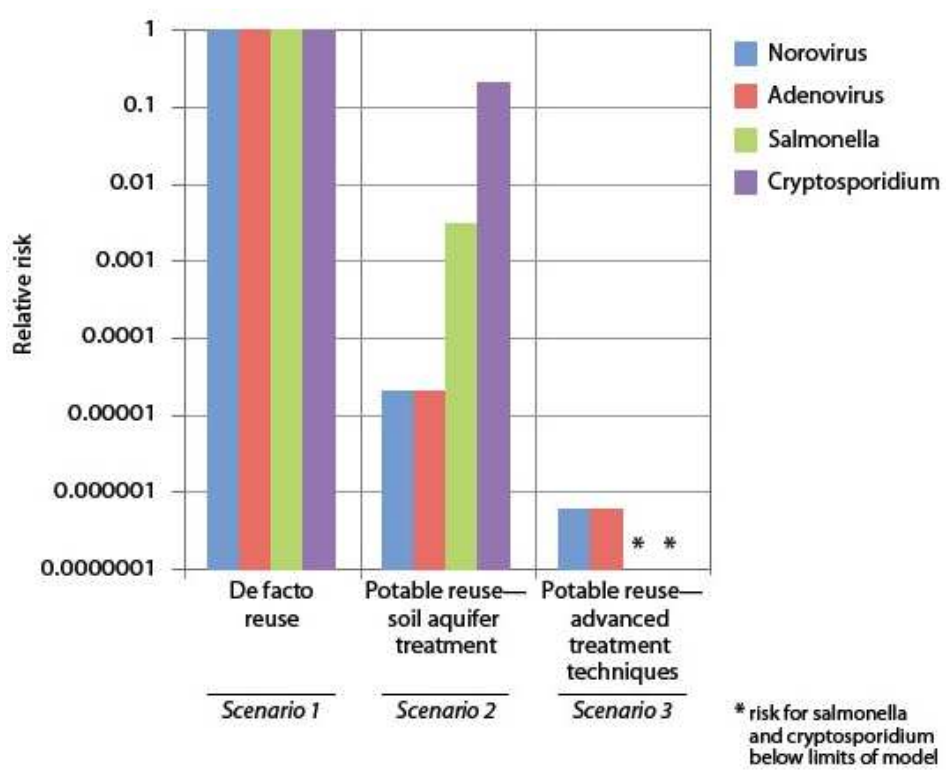

Figure 4. Relative risk, shown on a logarithmic scale, posed by selected pathogens in a typical de facto reuse Scenario (1), compared to two potable reuse Scenarios (2, 3). The smaller the number, the lower the relative risk. For example in Scenario 2, the risk of illness due to Salmonella is estimated to be less than 1/100th of the risk due to Salmonella in Scenario 1. Overall, the results indicate the risk of exposure to these pathogens from drinking reclaimed water does not appear to be any higher than the risk experienced in at least some current drinking water treatment systems [11].

The results suggest that the risk of exposure to certain microbial and chemical contaminants from drinking reclaimed water does not appear to be any higher than the risk experienced in at least some current drinking water treatment systems and may, in fact, be orders of magnitude lower. The analysis revealed that carefully planned potable water reuse projects should be able to provide a level of protection from waterborne illness and chemical contaminants comparable to (and, in some cases, better than) the level of protection the public experiences in many drinking water supplies across the nation. However, researchers [11] pointed out that the analysis was presented as an example and should not be used to endorse certain treatment schemes or to determine the risk at any particular site without site-specific analysis $[7,9,11,33,48-53]$.

\section{Cost of Water Reuse Projects}

Investing in a water reuse system is a complex decision with both costs and benefits that extend many years into the future. Generally, water reuse is more expensive than drawing water from a natural freshwater source, but less expensive than seawater desalination. In many cases, lower-cost water sources are already being used, so the cost of water reuse should be compared with the cost of any available new water sources. The costs of water reuse vary greatly from place to place depending on location, water quality requirements, treatment methods, distribution system needs, energy costs [54], subsidies, and many other factors [11, 28, 50].

Potable reuse systems can be more or less expensive than non-potable reuse systems. Non-potable reuse may require less treatment, depending on the intended use of the reclaimed water, and can also reduce the peak demand on a potable system, which can be a huge factor on water use in arid locations. However, non-potable reuse also typically requires a separate piping system, which can be a significant expense depending on where and how far the non-potable water must be distributed [11].

Water managers should also consider non-monetary costs and benefits of reuse projects, such as increased water supply reliability in times of drought, greenhouse gas emissions, and ecological impacts, to determine the most socially, environmentally, and economically feasible water supply option for their community $[11,50]$.

\section{Public Preferences and Acceptability}

The public is a major stakeholder in any water management decision, and community members often play an important role in making decisions about water reuse projects. As with any water project, the success or failure of a proposed reuse project can ride on public perceptions of how the project relates to public health, public finance, taste and aesthetics, land use, environmental protection, and economic growth $[9$, $11,55,56]$.

Humans have a natural revulsion to water that is perceived to be contaminated, and sometimes that feeling can translate into opposition to reusing treated wastewater, even when reclaimed water is shown to be of high quality. In some cases, people may even prefer lower-quality water from a source perceived as "natural" over higher-quality water coming from an advanced wastewater treatment facility. Reclaimed water's history as wastewater causes a psychological barrier for many people that can be hard to overcome [11, 56-60].

However, when communities are actively engaged in discussions about water reuse, the technologies and science behind it, and the overall context of water management, both the public and water managers are better equipped to engage in meaningful dialogue $[11,56]$. 
In Redwood City, California, for example, a proposed water reclamation project was temporarily stalled by opposition from a small citizens' group in 2002. In response, a task force was established that brought the two sides together to discuss the project, review reliable sources of information, and weigh alternative options. A modified reuse project was eventually approved that was widely supported by the community. As the Redwood City experience demonstrates, frequent and open communication among water managers, citizens, and governments can be critical for communities to address the concerns of the public and make informed decisions about water reuse [11].

\section{Future Research Needs}

There are several existing potable reuse projects in the United States and abroad [5, 29]. Past research and operational data from existing indirect potable reuse facilities indicate that available technology can reduce chemical and microbial contaminants to levels comparable to or lower than those present in many current drinking water supplies. Notwithstanding the demonstrated safety of using highly-treated reclaimed water for indirect potable reuse, there are areas of research that could further advance the safety, reliability, and cost-effectiveness of indirect potable reuse and more clearly determine the acceptability of direct potable reuse as it relates to public health protection. Other future research needs may be related to new or alternative treatment unit processes or treatment trains that are proposed, regulatory requirements (e.g., constituent limits, monitoring, and analytical techniques), public acceptance, and other factors [50, 61].

Researchers [5] identified several key research needs related to both non-potable and potable reuse, which are summarized in Table 2.

Table 2. Research needs related to both non-potable and potable reuse [5].

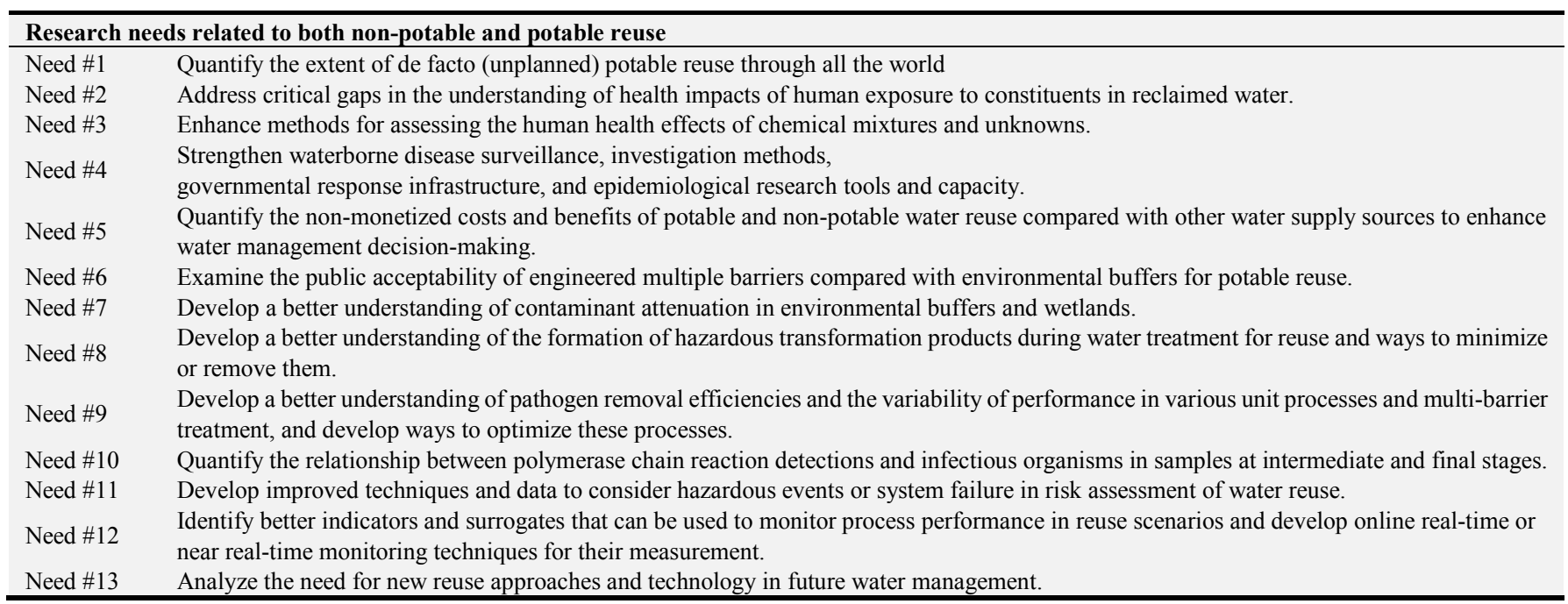

Figure 5. Shows suggested water recycling treatment and uses [6].

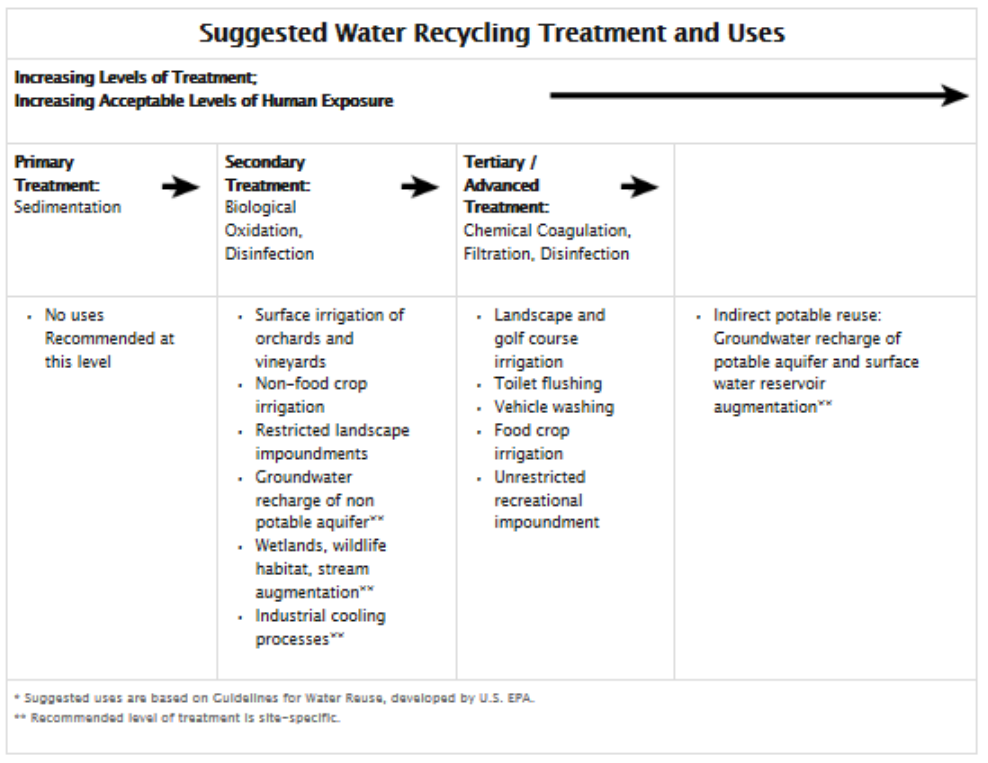

Figure 5. Suggested water recycling treatment and uses [6]. 


\section{Conclusions}

As mentioned by Cho [10], Dr. Shane Snyder, Professor of Environmental Engineering at the University of Arizona and a member of the science advisory panel [27], studied public perception of recycled water and found that "if they trust the utility, the majority of people understand that recycling water is unavoidable." The truth is that all water is being recycled over and over - no water on earth is truly pristine. Snyder concluded "We are going to drink recycled water one way or another, whether it comes from downstream flow or groundwater. I strongly believe we should to do it through engineered systems where we can actively control the process" [10].

Water reuse is becoming highly recommended through the entire world for strategical, environmental, technological and economic reasons. Comparatively to desalination option, in terms of economic considerations, water reuse is attracting more interest. Involved technologies in wastewater treatment plant for drinking water purpose should be furnished with highly performant methods such as membrane processes (nanofiltration, reverse osmosis) and advanced oxidation processes $\left(\mathrm{H}_{2} \mathrm{O}_{2}, \mathrm{O}_{3}\right.$, etc.). Future water treatment super-plants should be greatly sophisticated to treat both surface water and wastewater at the same elevated level of purity, since surface water is increasingly becoming polluted as wastewater microbiologically and chemically. Treating efficiently wastewater at its source is the best "barrage" against pollutants diffusion through the nature as CECs are detected in tap water.

\section{References}

[1] D. Ghernaout, Water reuse (WR): The ultimate and vital solution for water supply issues, Intern. J. Sustain. Develop. Res. 3 (2017) 36-46.

[2] N. Nagabhatla, The water security paradigm: A new view for development planning,

https://thewaternetwork.com/_/integrated-water-resource-man agement-iwrm/blog-Jl6/the-water-security-paradigm-a-new-vi ew-for-development-planning-EGhYpHg2cGtY2rlenpJQPw (accessed on 3/10/17).

[3] R. C. Brears, Future water utility: Wastewater is not waste, https://youngwaterleaders.thewaternetwork.com/article-FfV/fu ture-water-utility-wastewater-is-not-waste-gYsLACCzbKqxm t2XaTjwAQ (accessed on 3/10/17).

[4] The importance of clean water, http://www.gracelinks.org/2382/the-importance-of-clean-wate r (accessed on 4/10/17).

[5] Guidelines for water reuse, US Environmental Protection Agency, Office of Wastewater Management, Office of Water, Washington, D.C., EPA/600/R-12/618, September 2012, https://nepis.epa.gov/Adobe/PDF/P100FS7K.pdf (accessed on 6/10/17).

[6] Water Recycling and Reuse: The Environmental Benefits, https://www3.epa.gov/region9/water/recycling/ (accessed on $6 / 10 / 17)$.
[7] A. C. Maizel, C. K. Remucal, The effect of advanced secondary municipal wastewater treatment on the molecular composition of dissolved organic matter, Water Res. 122 (2017) $42-52$.

[8] B. Zhang, X. Song, L. D. Nghiem, G. Li, W. Luo, Osmotic membrane bioreactors for wastewater reuse: Performance comparison between cellulose triacetate and polyamide thin film composite membranes, J. Membr. Sci. 539 (2017) 383-391.

[9] M. M. Saggaï, A. Ainouche, M. Nelson, F. Cattin, A. El Amrani, Long-term investigation of constructed wetland wastewater treatment and reuse: Selection of adapted plant species for metaremediation, J. Environ. Manage. 201 (2017) $120-128$.

[10] R. Cho, From wastewater to drinking water (4/04/2011), http://blogs.ei.columbia.edu/2011/04/04/from-wastewater-to-d rinking-water/ (accessed on 3/10/17).

[11] Understanding water reuse: Potential for expanding the nation's water supply through reuse of municipal waste water, $\mathrm{http}: / /$ nas-sites.org/waterreuse/ (accessed on 4/10/17).

[12] W. Henley, The new water technologies that could save the planet $(22 / 07 / 2013)$,

https://www.theguardian.com/sustainable-business/new-watertechnologies-save-planet (accessed on 4/10/17).

[13] Following the flow, an inside look at wastewater treatment, Water Environment Federation, 2009,

https://www.wef.org/globalassets/assets-wef/3---resources/forthe-public/public-information/following-the-flow-book-an-ins ide-look-at-wastewater-treatment.pdf (accessed on 6/10/17).

[14] S. Naidoo, A. O. Olaniran, Treated wastewater effluent as a source of microbial pollution of surface water resources, Int. J. Environ. Res. Public Health 11 (2014) 249-270.

[15] M. A. Al-Obaidi, C. Kara-Zaïtri, I. M. Mujtaba, Removal of phenol from wastewater using spiral-wound reverse osmosis process: Model development based on experiment and simulation, J. Water Process Eng. 18 (2017) 20-28.

[16] Sewage treatment, https://en.wikipedia.org/wiki/Sewage_treatment (accessed on 4/10/17).

[17] Y. Yang, Y. S. Ok, K.-H. Kim, E.E. Kwon, Y.F. Tsang, Occurrences and removal of pharmaceuticals and personal care products (PPCPs) in drinking water and water/sewage treatment plants: A review, Sci. Total Environ. 596-597 (2017) 303-320.

[18] New York City's wastewater treatment system, http://www.nyc.gov/html/dep/html/wastewater/wwsystem-pro cess.shtml (accessed on 3/10/17).

[19] G. K. Haines, Is this water recycled sewage?, February 2011, https://www.acs.org/content/dam/acsorg/education/resources/h ighschool/chemmatters/recycled-sewage.pdf (accessed on 6/10/17).

[20] K. Gomes, Wastewater management, Oxford Book Company, Jaipur, India, 2009.

[21] H. Wang, M. Park, H. Liang, S. Wu, I. J. Lopez, W. Ji, G. Li, S. A. Snyder, Reducing ultrafiltration membrane fouling during potable water reuse using pre-ozonation, Water Res. 125 (2017) 42-51. 
[22] O. Ivarsson, A. Olander, Risk assessment for South Africa's first direct wastewater reclamation system for drinking water production, Beaufort West, South Africa, Master of Science Thesis, Chalmers University of Technology, Göteborg, Sweden, 2011.

[23] P. Marais, F. von Dürckheim, Beaufort West Water Reclamation Plant: First direct (toilet-to-tap) water reclamation plant in South Africa, $75^{\text {th }}$ IMESA Conference, Northern Provinces, 63-64, 2011.

[24] N. Abdel-Raouf, A. A. Al-Homaidan, I. B. M. Ibraheem, Microalgae and wastewater treatment, Saudi J. Biolog. Sci. 19 (2012) 257-275.

[25] E. Schroeder, G. Tchobanoglous, H. L. Leverenz, T. Asano, Direct potable reuse: Benefits for public water supplies, agriculture, the environment, and energy conservation, National Water Research Institute, Fountain Valley, California, http://www.nwri-usa.org/documents/NWRIWhitePaperDPRBe nefitsJan2012.pdf (accessed on 4/10/17).

[26] Ground water and drinking water, https://www.epa.gov/ground-water-and-drinking-water (accessed on 3/10/17).

[27] P. Anderson, N. Denslow, J.E. Drewes, A. Olivieri, D. Schlenk, S. Snyder, Monitoring strategies for chemicals of emerging concern (CECs) in recycled water, Recommendations of a Science Advisory Panel, Final Report, State Water Resources Control Board, June 25, 2010, Sacramento, California, 2017; 3(4): 36-46 (accessed on 3/10/17).

[28] S. Hosseinzadeh, G. Bonarrigo, Y. Verheust, P. Roccaro, S. Van Hulle, Water reuse in closed hydroponic systems: Comparison of GAC adsorption, ion exchange and ozonation processes to treat recycled nutrient solution, Aquacult. Eng. 78 (2017) 190-195.

[29] P. Vergine, C. Salerno, A. Libutti, L. Beneduce, G. Gatta, G. Berardi, A. Pollice, Closing the water cycle in the agro-industrial sector by reusing treated wastewater for irrigation, J. Clean. Prod. 164 (2017) 587-596.

[30] S. M. Hocaoglu, Evaluations of on-site wastewater reuse alternatives for hotels through water balance, Resour. Conserv. Recyc. 122 (2017) 43-50.

[31] A. Nikoonahad, M. T. Ghaneian, A. H. Mahvi, M. H. Ehrampoush, A. A. Ebrahimi, M. H. Lotfi, S. Salamehnejad, Application of novel Modified Biological Aerated Filter (MBAF) as a promising post-treatment for water reuse: Modification in configuration and backwashing process, J. Environ. Manage. 203 (2017) 191-199.

[32] A. Margenat, V. Matamoros, S. Díez, N. Cañameras, J. Comas, J. M. Bayona, Occurrence of chemical contaminants in peri-urban agricultural irrigation waters and assessment of their phytotoxicity and crop productivity, Sci. Total Environ. 599-600 (2017) 1140-1148.

[33] G. Fongaro, A. Kunz, M. E. Magri, C. D. Schissi, A. Viancelli, L. S. Philippi, C. R. M. Barardi, Settling and survival profile of enteric pathogens in the swine effluent for water reuse purpose, Intern. J. Hygiene Environ. Health 219 (2016) 883-889.

[34] S. Vajnhandl, J. V. Valh, The status of water reuse in European textile sector, J. Environ. Manage. 141 (2014) 29-35.

[35] J. Chang, W. Lee, S. Yoon, Energy consumptions and associated greenhouse gas emissions in operation phases of urban water reuse systems in Korea, J. Clean. Prod. 141 (2017)
728-736.

[36] I. B. Law, Advanced reuse - from Windhoek to Singapore and beyond, Water, May, 2003.

[37] Reclaimed water, https://en.wikipedia.org/wiki/Reclaimed_water (accessed on 4/10/17).

[38] D. Abdulbaki, M. Al-Hindi, A. Yassine, M. Abou Najm, An optimization model for the allocation of water resources, J. Clean. Prod. 164 (2017) 994-1006.

[39] Z. Chen, Q. Wu, G. Wu, H.-Y. Hu, Centralized water reuse system with multiple applications in urban areas: Lessons from China's experience, Resour. Conserv. Recyc. 117 (2017) 125-136.

[40] Australian guidelines for water recycling: Managing health and environmental Risks (phase1), Natural Resource Management Ministerial Council Environment Protection and Heritage Council Australian Health Ministers' Conference, National Water Quality Management Strategy, November 2006, https://www.environment.gov.au/system/files/resources/044e7 a7e-558a-4abf-b985-2e831d8f36d1/files/water-recycling-guid elines-health-environmental-21.pdf (accessed on 6/10/17).

[41] C. Wang, Y. Hou, Y. Xue, Water resources carrying capacity of wetlands in Beijing: Analysis of policy optimization for urban wetland water resources management, J. Clean. Prod. 161 (2017) 1180-1191.

[42] L. Wang, B. Batchelor, S. D. Pillai, V. S. V. Botlaguduru, Electron beam treatment for potable water reuse: Removal of bromate and perfluorooctanoic acid, Chem. Eng. J. 302 (2016) 58-68.

[43] S. D. Richardson, S. Y. Kimura, Emerging environmental contaminants: Challenges facing our next generation and potential engineering solutions, Environ. Technol. Innov. 8 (2017) 40-56.

[44] E. Hassanzadeh, M. Farhadian, A. Razmjou, N. Askari, An efficient wastewater treatment approach for a real woolen textile industry using a chemical assisted NF membrane process, Environ. Nanotechnol. Monitor. Manage. 8 (2017) 92-96.

[45] M. M. M. Tin, G. Anioke, O. Nakagoe, S. Tanabe, H. Kodamatani, L. D. Nghiem, T. Fujioka, Membrane fouling, chemical cleaning and separation performance assessment of a chlorine-resistant nanofiltration membrane for water recycling applications, Sep. Purif. Technol. 189 (2017) 170-175.

[46] G. W. H. Simons, W. G. M. Bastiaanssen, W. W. Immerzeel, Water reuse in river basins with multiple users: A literature review, J. Hydrol. 522 (2015) 558-571.

[47] B. J. Blunt, A. Singh, L. Wu, M. Gamal El-Din, M. Belosevic, K. B. Tierney, Reuse water: Exposure duration, seasonality and treatment affect tissue responses in a model fish, Sci. Total Environ. 607-608 (2017) 1117-1125.

[48] O. M. Rodriguez-Narvaez, J. M. Peralta-Hernandez, A. Goonetilleke, E. R. Bandala, Treatment technologies for emerging contaminants in water: A review, Chem. Eng. J. 323 (2017) 361-380.

[49] T. L. S. Silva, S. Morales-Torres, S. Castro-Silva, J. L. Figueiredo, A. M. T. Silva, An overview on exploration and environmental impact of unconventional gas sources and treatment options for produced water, J. Environ. Manage. 200 (2017) 511-529. 
[50] J. G. Herman, C. E. Scruggs, B. M. Thomson, The costs of direct and indirect potable water reuse in a medium-sized arid inland community, J. Water Process Eng. 19 (2017) 239-247.

[51] Q. K. Tran, D. Jassby, K. A. Schwabe, The implications of drought and water conservation on the reuse of municipal wastewater: Recognizing impacts and identifying mitigation possibilities, Water Res. 124 (2017) 472-481.

[52] A. Ding, H. Liang, G. Li, I. Szivak, J. Traber, W. Pronk, A low energy gravity-driven membrane bioreactor system for grey water treatment: Permeability and removal performance of organics, J. Membr. Sci. 542 (2017) 408-417.

[53] G. Almeida, J. Vieira, A. S. Marques, A. Kiperstok, A. Cardoso, Estimating the potential water reuse based on fuzzy reasoning, J. Environ. Manage. 128 (2013) 883-892.

[54] C.-M. Lam, L. Leng, P.-C. Chen, P.-H. Lee, S.-C. Hsu, Eco-efficiency analysis of non-potable water systems in domestic buildings, Appl. Energ. 202 (2017) 293-307.

[55] A. Giwa, A. Dindi, An investigation of the feasibility of proposed solutions for water sustainability and security in water-stressed environment, J. Clean. Prod. 165 (2017) 721-733.

[56] S. Bakopoulou, A. Kungolos, Investigation of wastewater reuse potential in Thessaly region, Greece, Desalination 248 (2009) 1029-1038.
[57] S. Jia, Y. Han, H. Zhuang, H. Han, K. Li, Simultaneous removal of organic matter and salt ions from coal gasification wastewater RO concentrate and microorganisms succession in a MBR, Bioresource Technol. 241 (2017) 517-524.

[58] B. G. Choi, M. Zhan, K. Shin, S. Lee, S. Hong, Pilot-scale evaluation of FO-RO osmotic dilution process for treating wastewater from coal-fired power plant integrated with seawater desalination, J. Membr. Sci. 540 (2017) 78-87.

[59] A. Bellver-Domingo, R. Fuentes, F. Hernández-Sancho, Shadow prices of emerging pollutants in wastewater treatment plants: Quantification of environmental externalities, J. Environ. Manage. 203 (2017) 439-447.

[60] I. Vázquez-Rowe, R. Kahhat, Y. Lorenzo-Toja, Natural disasters and climate change call for the urgent decentralization of urban water systems, Sci. Total Environ. 605-606 (2017) 246-250.

[61] B. M. Pecson, S. C. Triolo, S. Olivieri, E. C. Chen, A. N. Pisarenko, C.-C. Yang, A. Olivieri, C. N. Haas, R. S. Trussell, R. R. Trussell, Reliability of pathogen control in direct potable reuse: Performance evaluation and QMRA of a full-scale 1 MGD advanced treatment train, Water Res. 122 (2017) 258-268. 